\title{
Chlorogenic acid against palmitic acid in endoplasmic reticulum stress-mediated apoptosis resulting in protective effect of primary rat hepatocytes
}

\author{
Yong Zhang ${ }^{1}$, Liangsheng Miao ${ }^{2}$, Huijuan Zhang ${ }^{1}$, Gang Wu${ }^{1}$, Zhenni Zhang ${ }^{1}$ and Jianrui $\mathrm{Lv}^{1 *}$
}

\begin{abstract}
Background: We demonstrated growing evidence supports a protective role of chlorogenic acid of rat hepatocytes elicited by two compounds, i.e. thapsigargin and palmitic acid. Nevertheless, little is known about the mechanisms of palmitic acid induced endoplasmic reticulum (ER) stress and cell death.

Methods: The proliferation of primary rat hepatocytes was detected by MTT assay. The expression of GRP78, CHOP and GRP94 was detected by Western blot analyses.

Caspase-3 activity was detected by a Caspase-3 substrate kit. Cell apoptosis was detected by Hoechst 33342 staining.

Results: We demonstrated that incubation of hepatocytes for $16 \mathrm{~h}$ with palmitic acid elevated cell death. Moreover, Western blot analyses demonstrated increased levels of the endoplasmic reticulum stress markers - glucose regulated protein 78 (GRP78), C/EBP homologous protein (CHOP), and glucose regulated protein 94 (GRP94). Chlorogenic acid could inhibit ER stress induced cell death and levels of indicators of ER stress caused by palmitic acid. The effect of thapsigargin, which evokes ER stress were reversed by chlorogenic acid.
\end{abstract}

Conclusions: Altogether, our data indicate that in primary rat hepatocytes, chlorogenic acid prevents ER stressmediated apoptosis of palmitic acid.

Keywords: Palmitic acid, Chlorogenic acid, ER stress, Hepatocytes, Liver

\section{Introduction}

Hepatocyte death is associated with almost every hepatopathy.

In recent studies, thapsigargin (TG) has found such widespread use since it pumps $\mathrm{Ca}^{2+}$ from the cytosol into the lumen of the endoplasmic reticulum (ER) in cells [1].

During the last thirty years, the mechanism of TG action has been illustrated thoroughly [2]. As we all know that raising of intracellular free calcium $\left(\left[\mathrm{Ca}^{2+}\right] \mathrm{i}\right)$ may cause cell death in many cells such as hepatocytes [3].

Saturated fatty acids (FA) including palmitic acid may cause apoptosis and ER stress in rat and human liver cell

\footnotetext{
* Correspondence: jianruilv@gmail.com

${ }^{1}$ Department of Anesthesiology, Second Affiliated Hospital of Xi'an Jiaotong University, No. 157, West 5th Road, Xi'an 710004, Shaanxi Province, China Full list of author information is available at the end of the article
}

lines [4-8], which will result in degeneration and/or inflammation.

The assumption is confirmed by the fact that palmitic acid induced ER stress and apoptosis are founded in mice and rats $[9,10]$.

Mechanisms of hepatotoxicity are complex and one drug may have several toxic mechanisms occurring at the same time or sequentially.

Coffee has higher concentration of polyphenols among the beverages [11] . Chlorogenic acid is the major polyphenol in coffee. There are a large number of phenolics exited in promotive health foods and in the plant kingdom, such as vegetables and fruits. Phenolics are also commonly found in beverages made from plants, such as tea, coffee, and wine [12]. In numerous biological tests, Chlorogenic acid has been proved to have superoxide anion-scavenging effects, in other words, it has the

(C) The Author(s). 2018 Open Access This article is distributed under the terms of the Creative Commons Attribution 4.0 International License (http://creativecommons.org/licenses/by/4.0/), which permits unrestricted use, distribution, and 
ability to suppress hepatitis B virus and to restrain lipid peroxidation. According to the study, the restriction of ER stress may cause the protective effect of chlorogenic acid in $\mathrm{CCl}_{4}$-treated rats [13]. Chlorogenic acid induce apoptosis in several types of cancer cells in vitro [14-16]. However, until now, we have very limited information to prove the toxicity of polyphenols and related phenolics to normal cells. According to recent studies, chlorogenic acid is likely to reduce the risk of oxidative cell death [17-19].

In the present study, whether the chlorogenic acid could protect rat primary hepatocytes and conduce to clinically-relevant ER stress inducer such as palmitic acid was examined. In this paper, we report that: (1) palmitic acid could induce ER stress and apoptosis in hepatocytes; (2) chlorogenic acid could reduce cell death induced by palmitic acid; (3) with specific attention given to GRP78, GRP94 and $\mathrm{CHOP}$, we can adjust the effects through alteration of the ER stress.

\section{Materials and methods}

\section{Materials and cells}

Hepatocytes were prepared as previously described [20]. The cells were plated on $35-\mathrm{mm}$ diameter culture plates $\left(1 \times 10^{6}\right.$ cells/plate $)$ in M199 containing $1 \%(v / v)$ antibiotics $(10 \mathrm{U} / \mu \mathrm{g}$ penicillin, $10 \mu \mathrm{g} / \mu \mathrm{L}$ streptomycin), 100 $\mathrm{nM}$ dexamethasone, $0.5 \mathrm{nM}$ insulin and $4 \%(v / \mathrm{v})$ NCS. After initial $4 \mathrm{~h}$ incubation for the attachment of the cells to the substratum, the medium was changed to Williams' medium E $1 \%(\mathrm{v} / \mathrm{v})$ antibiotics $(10 \mathrm{U} / \mu \mathrm{g}$ penicillin, $10 \mu \mathrm{g} / \mu \mathrm{L}$ streptomycin), $100 \mathrm{nM}$ dexamethasone and $0.5 \mathrm{nM}$ insulin without NCS. Experimental treatments were performed after $44 \mathrm{~h}$ of culture in Williams' medium E containing $1 \%(\mathrm{v} / \mathrm{v})$ antibiotics and $100 \mathrm{nM}$ dexamethasone.

\section{Incubation of hepatocytes}

The cells at $85-95 \%$ confluence, were incubated with palmitic acid $(250 \mu \mathrm{mol} / \mathrm{l})$ or thapsigargin $(5 \mu \mathrm{mol} / \mathrm{l})$ for up to $16 \mathrm{~h}$. Then hepatocytes were incubated with palmitic acid $(250 \mu \mathrm{mol} / \mathrm{l})$ with/without chlorogenic acid (1 or $5 \mu \mathrm{mol} / \mathrm{l})$ for up to $16 \mathrm{~h}$.

\section{Measurement of cell viability and death}

Cell death was assessed by measurement of lactate dehydrogenase (LDH) from lysed cells, Annexin V Fluorescein (FITC) and propidium iodide (PI) double staining assay (BD Biosciences, USA) was used to quantify apoptosis rates using FACScan flow cytometer (Becton-Dickinson, USA). After treatment of morphine and oxycodone alone or together with nalmefene for $48 \mathrm{~h}$ in 6-well plates, cells were collected and wash with cold PBS. After centrifugation with $1000 \mathrm{r} / 3 \mathrm{~min}$, cells were re-suspended using $100 \mu \mathrm{l}$ binding buffer with $1 \times 10^{5}$ cells each group. Then Annexin V and PI were added according to instruction of test kits. After incubated for 15 mins at room temperature in the dark, samples were analyzed by flow cytometry. Cells without any treatment were used as negative control. Data was attained by analyzing early apoptotic rates (Annexin $\mathrm{V}+/ \mathrm{PI}-$ ) and late apoptotic rates (Annexin $\mathrm{V}+/ \mathrm{PI}+$ ).

\section{Measurement of caspase-3 activation}

Caspase-3 activity was evaluated using a DEVD-NucViewTM 488 Caspase-3 substrate kit (Biotium Inc., Cambridge, UK). In the presence of active caspase- 3 enzyme, the substrate dissociates from its bound fluorogenic DNA-binding dye and the latter binds to DNA and emits fluorescence. Caspase-3 was detected by microscopic examination and also by adapting the kit for microplate fluorescence reading. For this, cells were incubated with $50 \mu \mathrm{L}$ of $5 \mu \mathrm{mol} / \mathrm{L}$ DEVD-NucView ${ }^{\text {mo }} 488$ Caspase-3 substrate for $30 \mathrm{~min}$. Fluorescence was measured in a microplate reader (Cary Eclipse, Varian Inc.) set at wavelengths of $490 \mathrm{~nm}$ excitation and $520 \mathrm{~nm}$ emission.

\section{Western blot analysis}

Cells were washed in ice-cold PBS twice, and lysed in buffer with protease inhibitor, and phosphatase inhibitor, and then centrifuged at $13000 \times \mathrm{g}$ for $25 \mathrm{~min}$ at $4{ }^{\circ} \mathrm{C}$. The supernatant was collected and total proteins were quantified using bicinchoninic acid (Pierce, Rockford, AL, USA,) method. The protein samples were loaded onto polyacrylamide gel and subjected to sodium dodecyl sulfate polyacrylamide gel electrophoresis (SDS-PAGE). Proteins were then transferred onto a polyvinylidenedifluoride (PVDF) membrane. The membrane was blocked with Tris-buffered saline and Tween 20 (TBST) containing $4 \% \mathrm{BSA}$ for $1 \mathrm{~h}$ at room temperature. The membranes were incubated serially with primary antibodies at $4{ }^{\circ}$ Covernight. After washing with TBST 3 times for 8 min each, the membranes were incubated with secondary antibodies for $1 \pm 2 \mathrm{~h}$ at room temperature. The density of the corresponding bands was measured quantitatively using image analysis software (Bio-Red, Hercules, CA, USA) and corrected by reference to the value of $\beta$-actin.

\section{Statistical analysis}

All results were reported as mean \pm SD from three independent experiments. Cell survival, proliferation and differentiation among different groups were compared using SPSS statistical software (version 12.0). 
Statistical significance was determined using Student's t-test. $P<0.05$ was considered statistically significant.

\section{Results}

\section{Chlorogenic acid inhibited palmitic acid induced cell} death

Primary rat hepatocytes treated with $250 \mu \mathrm{mol} / \mathrm{l}$ palmitic and $5 \mu \mathrm{mol} / \mathrm{l}$ chlorogenic acid presented restored cell viability to levels observed in untreated cells (Fig. 1).

Compared with $5 \mu \mathrm{mol} / \mathrm{l}$ chlorogenic acid, $1 \mu \mathrm{mol} / \mathrm{l}$ chlorogenic acid showed weaker restored cell viability effects on primary rat hepatocytes.

\section{Chlorogenic acid reduces ER stress mediated by palmitic acid}

The immunoblot analysis revealed the presence of GRP78, GRP94 and CHOP After $16 \mathrm{~h}$ incubation with palmitic acid (Fig. 2).
We observed exposure of these cells to palmitic acid promoted up-regulation of ER stress markers. Co-incubation 1 or $5 \mu \mathrm{mol} / \mathrm{l}$ chlorogenic acid reduced the levels of GRP78, GRP94 and CHOP after $16 \mathrm{~h}$ (Fig. 2).

\section{Chlorogenic acid reduced death caused by thapsigargin}

$5 \mu \mathrm{mol} / \mathrm{l}$ thapsigargin causes severe cell death (Fig. 3a). Eighter 1 or $5 \mu \mathrm{mol} / \mathrm{l}$ chlorogenic acid can significantly enhance cell vitality (Fig. 3a) which was confirmed by significant increases in both apoptosis and necrosis (Fig. 3b). $5 \mu \mathrm{mol} / \mathrm{l}$ chlorogenic acid increased cell death mediated by thapsigargin (Fig. 3b).

\section{Effects of chlorogenic acid on ER stress induced by thapsigargin}

$5 \mu \mathrm{mol} / \mathrm{l}$ chlorogenic acid decreased the elevated $\mathrm{CHOP}$ levels caused by $5 \mu \mathrm{mol} / \mathrm{l}$ thapsigargin (Fig. $4 \mathrm{a}, \mathrm{c}$ ). Neither $5 \mu \mathrm{mol} / \mathrm{l}$ nor $1 \mu \mathrm{mol} / \mathrm{l}$ concentration of chlorogenic
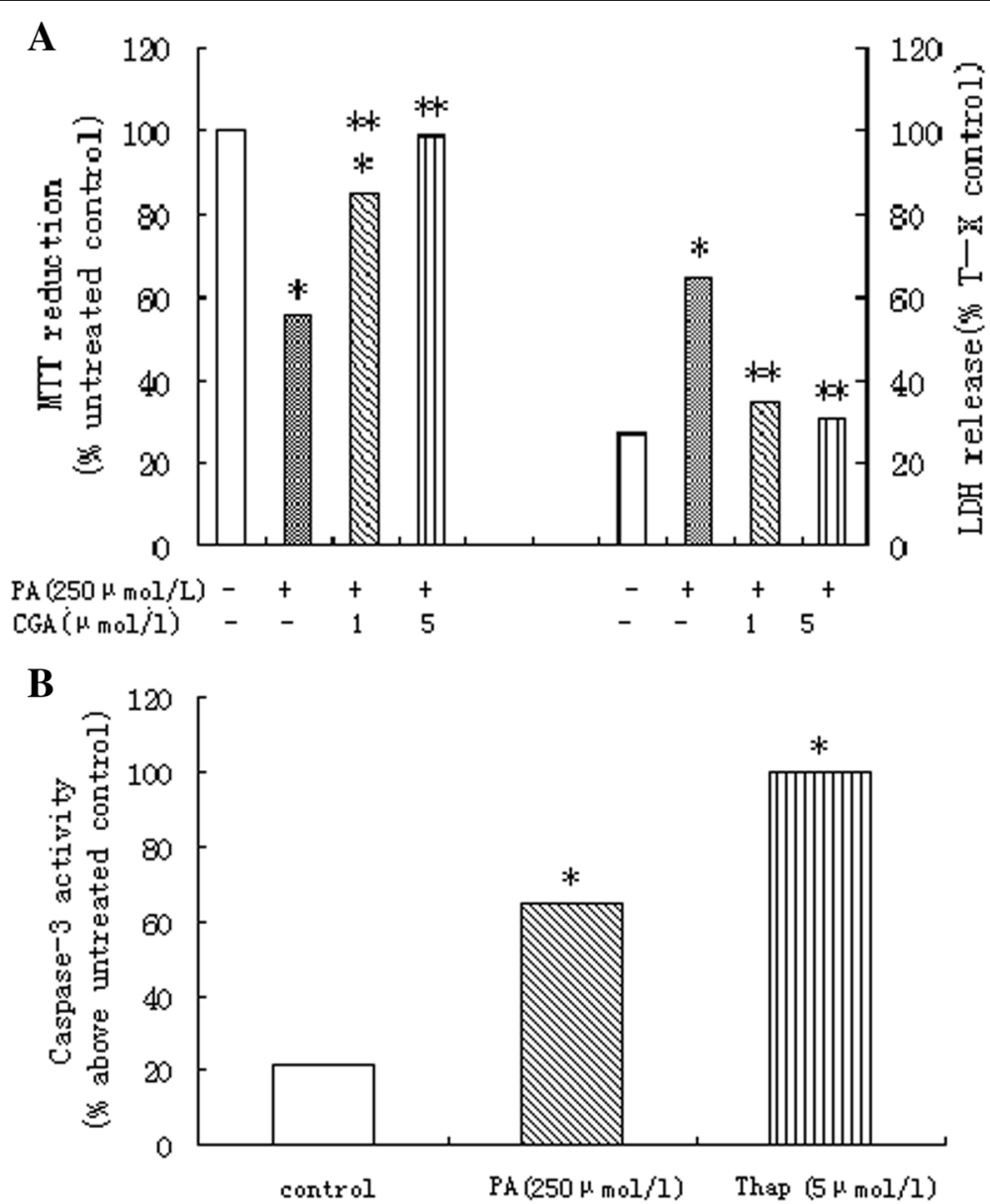

Fig. 1 a Primary rat hepatocytes treated with $250 \mu \mathrm{mol} / / \mathrm{p}$ palmitic and $5 \mu \mathrm{mol} / \mathrm{l}$ chlorogenic acid presented restored cell viability to levels observed in untreated cells on MTT reduction and LDH release. Data represent mean \pm S.E.M., $n=5,{ }^{*} P<0.05$ vs. control $(0 \mu \mathrm{mol} / \mathrm{l}$ palmitic acid), ${ }^{*} P<0.05$ vs. palmitic acid-only cells. b Treatment of primary rat hepatocytes with $250 \mu \mathrm{mol} / \mathrm{L}$ palmitic acid produced a significant increase in activity of caspase-3. For comparison, the effects of thapsigargin(Thap; $5 \mu$ mol//)are also shown. Data represent mean \pm S.E.M., $n=5,{ }^{*} P<0.05$ vs. control $\left(0 \mu \mathrm{mol} / / \mathrm{l}\right.$ palmitic acid), ${ }^{* *} P<0.05$ vs. palmitic acid-only cells. 


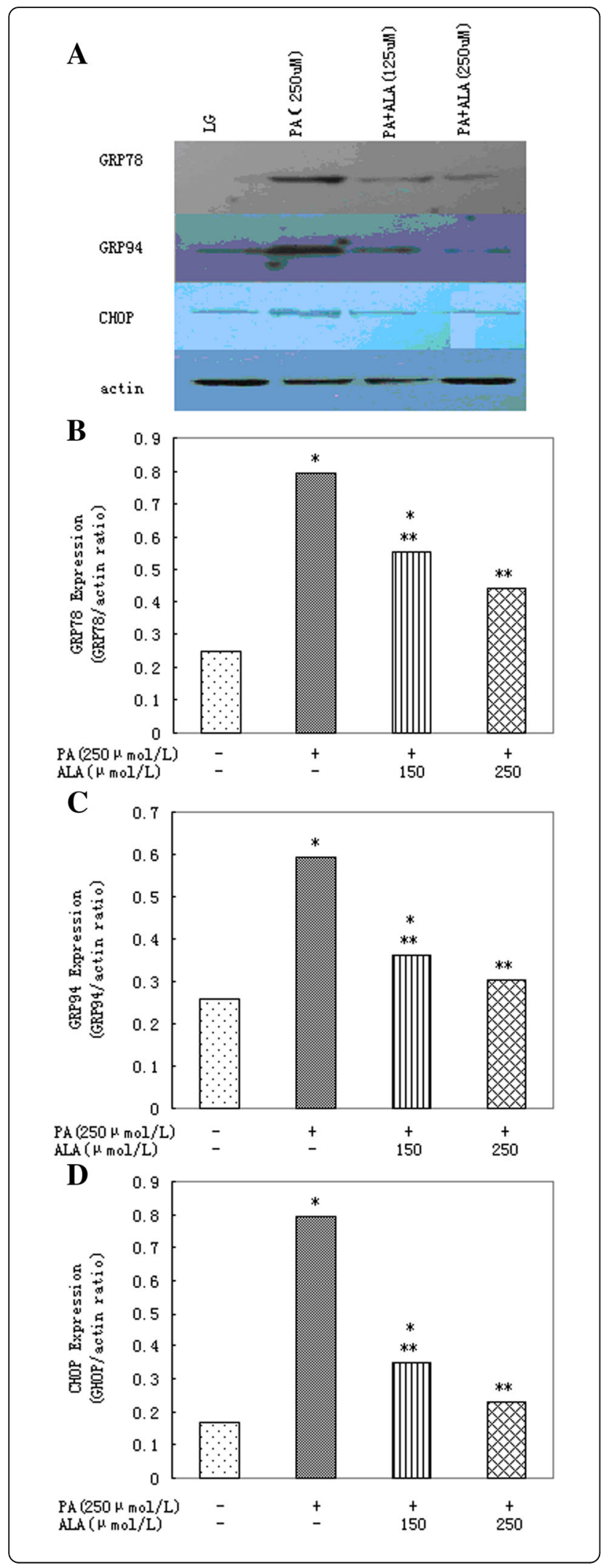

Fig. 2 Chlorogenic acid protects primary rat hepatocytes against ER stress induced by palmitic acid. a Western blot and (b) densitometric analysis demonstrating the reduction of palmitic acid (PA)-induced GRP78 expression by 1 or $5 \mu \mathrm{mol} / \mathrm{l}$ chlorogenic acid (CGA) after $16 \mathrm{~h}$. a Western blot and (c) densitometric analysis of GRP94 expression after $16 \mathrm{~h}$ incubation of cells with $250 \mathrm{\mu mol} / \mathrm{l}$ palmitic acid (PA) in presence of 1 or $5 \mu \mathrm{mol} / /$ chlorogenic acid (CGA). a Western blot and (d) densitometric analysis demonstrating the reduction of palmitic acid (PA)-induced CHOP expression by 1 or $5 \mu \mathrm{mol} / \mathrm{l}$ chlorogenic acid (CGA) after 16 h. Data represent mean \pm S.E.M., $n=5$, ${ }^{*} P<0.05$ vs. LG, low glucose control $\left(0 \mu \mathrm{mol} / \mathrm{l}\right.$ palmitic acid), ${ }^{* *} P<0.05$ vs. palmitic acid only cells

acid could reduce GRP78 expression mediated by thapsigargin (Fig. 4a, b).

\section{Discussion}

The objectives of this study were to find out whether chlorogenic acid could prevent palmitic acid induced ER stress and the cell death in liver cells. It has been reported in many cell lines that apoptosis via endoplasmic reticulum (ER) stress. ER stress plays a significant role in many liver diseases.

We go into the effects of chlorogenic acid and palmitic acid, and their combined action about resulting in apoptosis, cell death, ER stress and caspase- 3 activity in hepatocytes. We detected the three ER stress markers.

This phenomenon, called lipotoxicity, has been related to cardiac failure, NAFLD and diabetes [21-24] . UPR activation was founded in NAFLD, cardiac dysfunction and hyperadiposis $[25,26]$.

Activation the UPR caused ER stress and cell death, which is bring out by an excess of saturated fatty acids in many cell types [4, 27-29]. Palmitic acid activates ER stress and has been suggested to play a crucial role in the NAFLD. Therefore, damages in ER stabilization is the cause of many diseases and contributes to lipotoxicity. The purpose of our study is to find out the relationship between the saturated fatty acids and ER stress. Our study indicates that (1) chlorogenic acid can reduce cellular dysfunction and apoptosis caused by thapsigargin. (2) chlorogenic acid can reduce cellular dysfunction and apoptosis caused by palmitic acid. (3) by reducing ER stress and apoptosis, chlorogenic acid protects hepatocytes from palmitic acid's lipotoxicity.

Thapsigargin gives rise to necrosis and apoptosis in many cells [30-32]. We are not clear about how the thapsigargin works to give rise to necrosis and apoptosis. It is possible that chlorogenic acid reduced damages of primary rat hepatocytes by protecting cells against thapsigargin-induced apoptosis. 


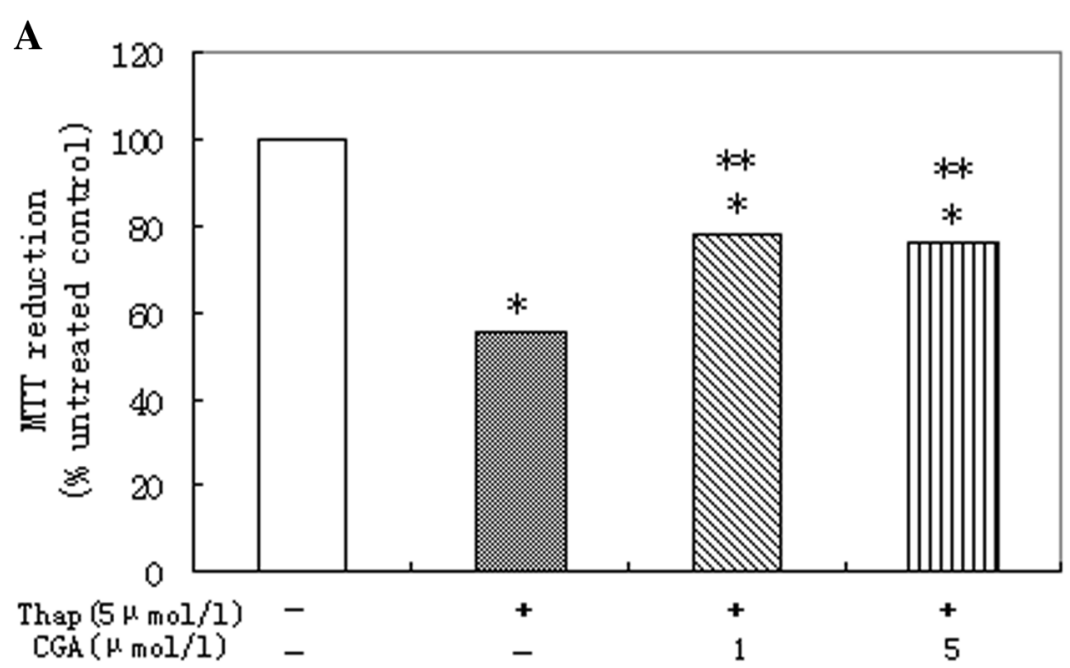

B

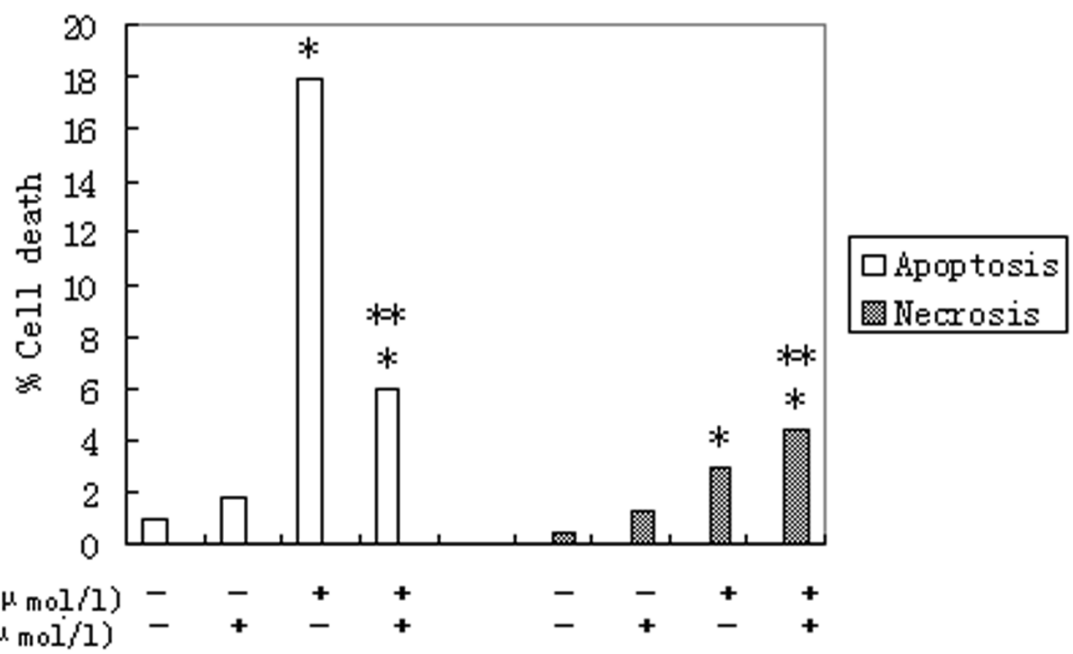

Fig. 3 Chlorogenic acid protects against dysfunction and apoptosis of primary rat hepatocytes induced by thapsigargin. a MTT reduction. b Cell death. Relative cell death treated with $5 \mu \mathrm{mol} / \mathrm{l}$ thapsigargin (Thap) for $16 \mathrm{~h}$ in presence of 1 or $5 \mu \mathrm{mol} / \mathrm{l}$ chlorogenic acid (CGA). Data represent mean \pm S.E.M., $n=5,{ }^{*} P<0.05$ vs. LG, low glucose control set to $1\left(0 \mu \mathrm{mol} / /\right.$ thapsigargin), ${ }^{*} P<0.05$ vs. thapsigargin-only cells

A number of recent studies have pointed out that many ER stress markers were active during saturated fatty acid-induced apoptosis $[4,33,34]$.

Chlorogenic acid has been extensively studied since it is widely distributed in plants, which is one of the main polyphenols in the human diet, and it possesses many health-promoting properties. So, it has the potential to become a health product such as functional food and nutraceuticals.

Functional food and nutraceuticals have the potential to become the future of primary prevention in dyslipidaemia treatment in many diseases [35]. Because of the limited production conditions, it has not been popularized in the market.

Chlorogenic acid has multifunctional properties as a nutraceutical and food additive. As a nutraceutical, chlorogenic acid has anti-oxidant, anti-inflammatory, anti-obesity, antidyslipidemia, antidiabetic, and antihypertensive properties, which can serve for the prevention and treatment of metabolic syndrome and associated disorders [36].

Our follow-up work will focus on animal experiments, which will be done to prove that the in vitro results can be reproduced in the animals. And lack of preclinical tox studies of cholorgenic acid is also a deficiency of our research work. We will make up for it in the work of future research.

\section{Conclusions}

Chlorogenic acid, the major polyphenol in coffee can reduce ER stress produced by palmitic acid. Chlorogenic acid afford protective effect by reduce ER stress. Caspase-3 and $\mathrm{CHOP}$ was associated with lipotoxicity of palmitic acid.

Polyphenol such as chlorogenic acid may protect hepatocytes against palmitic acid. 


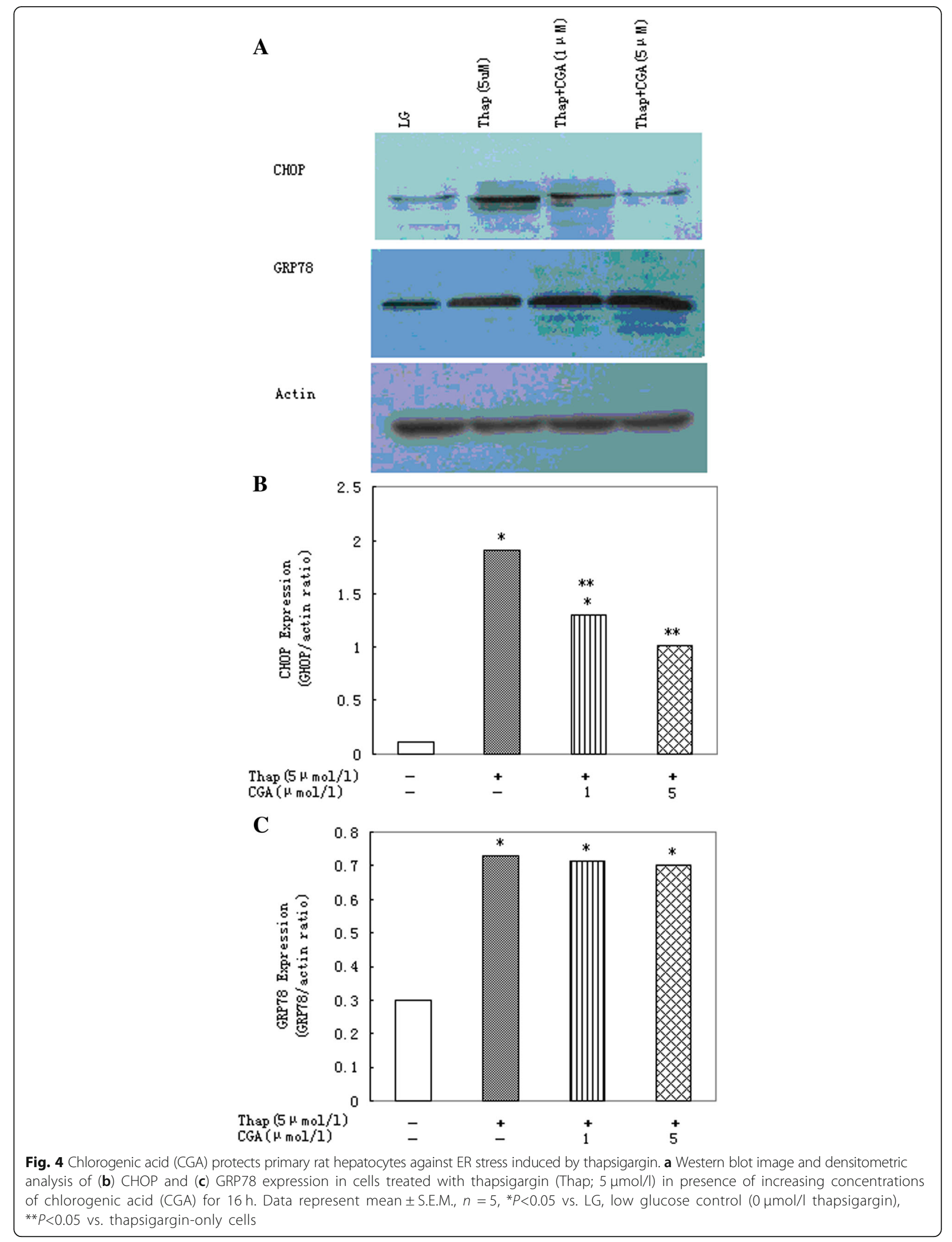




\section{Abbreviations}

CHOP: C/EBP homologous protein; ER: Endoplasmic reticulum; GRP78: Glucose regulated protein 78; GRP94: Glucose regulated protein 94; LDH: Lactate dehydrogenase

\section{Acknowledgements}

We thank laboratory of Tissue Engineering, the Air force medical university, for guidance of primary cell culture.

\section{Funding}

The Project Supported by Natural Science Basic Research Plan in Shaanxi Province of China (Program No.2014JM2-3034).

\section{Availability of data and materials}

The data that support the findings of this study are available upon request to the corresponding author.

\section{Authors' contributions}

YZ conceived, designed and coordinated the work, as well as prepared the manuscript. JL was involved in the co-design of the work as well as the draft of the manuscript. LM, HZ and GW carried out analytical work and contributed in drafting the manuscript. JZ did the software work. All authors read and approved the final manuscript.

\section{Authors' information}

$Y Z$, a visiting staff of anesthesiology departmentt at the second affiliated hospital of Xi'an Jiaotong University, Shannxi Province, PR China. YZ graduated from Xi'an Jiaotong University and got his Ph.D degree in internal medicine. Since that time, He have been working for anesthesiology departmentt at the second affiliated hospital. His current research focuses on (1) Endoplasmic reticulum stress and Lipotoxicity (supported by the basic research plan of natural science in Shaanxi province 2014JM2-3034); (2) Chlorogenic Acid and hepatic protection (project supported by the supported by "the Fundamental Research Funds for the Central Universities", Granted No. 08143052).; (3) Endoplasmic reticulum stress and hepatic protection (supported by the funds of our hospital. YJQN.201301).

$J$, Professor, the director of anesthesiology departmentt at the second affiliated hospital of Xi'an Jiaotong University. He focused on "perioperative protection of viscera".

\section{Ethics approval and consent to participate}

This study was approved by the ethics committee of The Second Affiliated Hospital of Xi'an Jiaotong University and conducted in accordance with the ethics principles described by the Declaration of Helsinki.

\section{Consent for publication}

Not applicable.

\section{Competing interests}

The authors declare that they have no competing interests.

\section{Publisher's Note}

Springer Nature remains neutral with regard to jurisdictional claims in published maps and institutional affiliations.

\section{Author details}

${ }^{1}$ Department of Anesthesiology, Second Affiliated Hospital of Xi'an Jiaotong University, No. 157, West 5th Road, Xi'an 710004, Shaanxi Province, China. 2Department of Anesthesiology, Weinan Central Hospital, No.7, East of Chaoyang Road, Weinan 714000, Shaanxi Province, China.

Received: 9 June 2018 Accepted: 15 November 2018

Published online: 28 November 2018

\section{References}

1. Filgueiras OM, Possmayer F. Purification and characterization of a phospholipase A2 associated with rabbit lung microsomes: some evidence for its mitochondrial origin. Biochim Biophys Acta. 1990;1046:258-66.

2. Shukla N, Wan S, Angelini GD, Jeremy JY. Low nanomolar thapsigargin inhibits the replication of vascular smooth muscle cells through reversible endoplasmic reticular stress. Eur J Pharmacol. 2013;714:210-7.
3. Ueda T, Takeyama Y, Hori Y, Takase K, Goshima M, Kuroda Y. Pancreatitisassociated ascitic fluid increases intracellular $\mathrm{ca}(2+)$ concentration on hepatocytes. J Surg Res. 2000;93:171-6.

4. Wei Y, Wang D, Topczewski F, Pagliassotti MJ. Saturated fatty acids induce endoplasmic reticulum stress and apoptosis independently of ceramide in liver cells. Am J Physiol Endocrinol Metab. 2006;291:E275-81.

5. Wei Y, Wang D, Pagliassotti MJ. Saturated fatty acid-mediated endoplasmic reticulum stress and apoptosis are augmented by trans-10, cis-12conjugated linoleic acid in liver cells. Mol Cell Biochem. 2007;303:105-13.

6. Mallik A, Yammani RR. Saturated fatty acid palmitate negatively regulates autophagy by promoting ATG5 protein degradation in meniscus cells. Biochem Biophys Res Commun. 2018;502(3):370-74. https://doi.org/10.1016/ j.bbrc.2018.05.172.

7. Hu X, Ge X, Liang W, Shao Y, Jing J, Wang C, Zeng R, Yao B. Effects of saturated palmitic acid and omega-3 polyunsaturated fatty acids on Sertoli cell apoptosis. Syst Biol Reprod Med. 2018;64(5):368-380. https://doi.org/10. 1080/19396368.2018.1471554

8. Wang Y, Liu J, Liu Z, Chen J, Hu X, Hu Y, Yuan Y, Wu G, Dai Z, Xu Y. Sall2 knockdown exacerbates palmitic acid induced dysfunction and apoptosis of pancreatic NIT-1 beta cells. Biomed Pharmacother. 2018;104:375-82.

9. Takahara I, Akazawa Y, Tabuchi M, Matsuda K, Miyaaki H, Kido Y, Kanda Y, Taura N, Ohnita K, Takeshima F, et al. Toyocamycin attenuates free fatty acid-induced hepatic steatosis and apoptosis in cultured hepatocytes and ameliorates nonalcoholic fatty liver disease in mice. PLoS One. 2017;12: e0170591.

10. Lee L, Ito T, Nakamura T, Jensen RT, Igarashi H, Takayanagi R. Antifibrotic effect of saturated fatty acids via endoplasmic reticulum stress response in rat pancreatic stellate cells. Pancreas. 2017:46:385-94.

11. Halvorsen BL, Carlsen MH, Phillips KM, Bohn SK, Holte K, Jacobs DR Jr, Blomhoff R. Content of redox-active compounds (ie, antioxidants) in foods consumed in the United States. Am J Clin Nutr. 2006;84:95-135.

12. Malejane DN, Tinyani $P$, Soundy $P$, Sultanbawa $Y$, Sivakumar D. Deficit irrigation improves phenolic content and antioxidant activity in leafy lettuce varieties. Food Sci Nutr. 2018;6:334-41.

13. Jin CF, Li B, Lin SM, Yadav RK, Kim HR, Chae HJ. Mechanism of the inhibitory effects of Eucommia ulmoides Oliv. Cortex extracts (EUCE) in the CCl 4 -induced acute liver lipid accumulation in rats. Int J Endocrinol. 2013;2013: 751854

14. Deka SJ, Gorai S, Manna D, Trivedi V. Evidence of PKC binding and translocation to explain the anticancer mechanism of Chlorogenic acid in breast Cancer cells. Curr Mol Med. 2017;17:79-89.

15. Liu YJ, Zhou CY, Qiu CH, Lu XM, Wang YT. Chlorogenic acid induced apoptosis and inhibition of proliferation in human acute promyelocytic leukemia HL60 cells. Mol Med Rep. 2013;8:1106-10.

16. Yang JS, Liu CW, Ma YS, Weng SW, Tang NY, Wu SH, Ji BC, Ma CY, Ko YC, Funayama S, Kuo CL. Chlorogenic acid induces apoptotic cell death in U937 leukemia cells through caspase- and mitochondria-dependent pathways. In Vivo. 2012;26:971-8.

17. Rebai O, Belkhir M, Sanchez-Gomez MV, Matute C, Fattouch S, Amri M. Differential molecular targets for neuroprotective effect of Chlorogenic acid and its related compounds against glutamate induced excitotoxicity and oxidative stress in rat cortical neurons. Neurochem Res. 2017;42:3559-72.

18. Wang X, Fan X, Yuan S, Jiao W, Liu B, Cao J, Jiang W. Chlorogenic acid protects against aluminium-induced cytotoxicity through chelation and antioxidant actions in primary hippocampal neuronal cells. Food Funct. 2017:8:2924-34

19. Ali N, Rashid S, Nafees S, Hasan SK, Shahid A, Majed F, Sultana S. Protective effect of Chlorogenic acid against methotrexate induced oxidative stress, inflammation and apoptosis in rat liver: an experimental approach. Chem Biol Interact. 2017;272:80-91.

20. Hespeling U, Jungermann K, Puschel GP. Feedback-inhibition of glucagonstimulated glycogenolysis in hepatocyte/Kupffer cell cocultures by glucagon-elicited prostaglandin production in Kupffer cells. Hepatology. 1995:22:1577-83.

21. Macchioni L, Petricciuolo M, Davidescu M, Fettucciari K, Scarpelli P, Vitale R, Gatticchi L, Orvietani PL, Marchegiani A, Marconi P, et al. Palmitate lipotoxicity in enteric glial cells: lipid remodeling and mitochondrial ROS are responsible for cyt c release outside mitochondria. Biochim Biophys Acta. 2018;1863:895-908.

22. Santos JDB, Mendonca AAS, Sousa RC, Silva TGS, Bigonha SM, Santos EC, Goncalves RV, Novaes RD. Food-drug interaction: anabolic steroids 
aggravate hepatic lipotoxicity and nonalcoholic fatty liver disease induced by trans fatty acids. Food Chem Toxicol. 2018;116:360-8.

23. Hu D, Xu Y, Xie J, Sun C, Zheng X, Chen W. Systematic evaluation of phenolic compounds and protective capacity of a new mulberry cultivar J33 against palmitic acid-induced lipotoxicity using a simulated digestion method. Food Chem. 2018;258:43-50.

24. Taram F, Winter AN, Linseman DA. Neuroprotection comparison of chlorogenic acid and its metabolites against mechanistically distinct cell death-inducing agents in cultured cerebellar granule neurons. Brain Res. 2016;1648:69-80.

25. Ueda K, Takimoto E, Lu Q, Liu P, Fukuma N, Adachi Y, Suzuki R, Chou S, Baur W, Aronovitz MJ, Greenberg AS, Komuro I, Karas RH. Membrane-initiated estrogen receptor signaling mediates metabolic homeostasis via central activation of protein phosphatase 2A. Diabetes. 2018;(8):1524-37. https://doi. org/10.2337/db17-1342.

26. Podolin DA, Sutherland E, Iwahashi M, Simon FR, Pagliassotti MJ. A highsucrose diet alters the lipid composition and fluidity of liver sinusoidal membranes. Horm Metab Res. 1998;30:195-9.

27. Pfaffenbach KT, Gentile CL, Nivala AM, Wang D, Wei Y, Pagliassotti MJ. Linking endoplasmic reticulum stress to cell death in hepatocytes: roles of C/EBP homologous protein and chemical chaperones in palmitatemediated cell death. Am J Physiol Endocrinol Metab. 2010;298:E1027-35.

28. Wei Y, Wang D, Gentile CL, Pagliassotti MJ. Reduced endoplasmic reticulum luminal calcium links saturated fatty acid-mediated endoplasmic reticulum stress and cell death in liver cells. Mol Cell Biochem. 2009;331:31-40.

29. Gunduz F, Aboulnasr FM, Chandra PK, Hazari S, Poat B, Baker DP, Balart LA Dash S. Free fatty acids induce ER stress and block antiviral activity of interferon alpha against hepatitis C virus in cell culture. Virol J. 2012;9:143.

30. Choi AY, Choi JH, Lee JY, Yoon KS, Choe W, Ha J, Yeo EJ, Kang I. Apigenin protects HT22 murine hippocampal neuronal cells against endoplasmic reticulum stress-induced apoptosis. Neurochem Int. 2010;57:143-52. https:/ doi.org/10.1016/j.neuint.2010.05.006

31. Tominaga R, Yamaguchi S, Satake C, Usui M, Tanji Y, Kondo K, Katagiri $H_{\text {, }}$ Oka Y, Ishihara H. The JNK pathway modulates expression and phosphorylation of 4E-BP1 in MIN6 pancreatic beta-cells under oxidative stress conditions. Cell Biochem Funct. 2010;28:387-93. https://doi.org/10. 1002/cbf.1667.

32. Zhao D, Liu Y, Liu X, Li T, Xin Z, Zhu X, Wu X, Liu Y. Erratum: HBV suppresses thapsigargin-induced apoptosis via inhibiting CHOP expression in hepatocellular carcinoma cells. Oncol Lett. 2017;14:8227.

33. Li Y, Zong $W X$, Ding WX. Recycling the danger via lipid droplet biogenesis after autophagy. Autophagy. 2017;13:1995-7.

34. Zhao MG, Sheng XP, Huang YP, Wang YT, Jiang $C H$, Zhang J, Yin ZQ. Triterpenic acids-enriched fraction from Cyclocarya paliurus attenuates nonalcoholic fatty liver disease via improving oxidative stress and mitochondrial dysfunction. Biomed Pharmacother. 2018;104:229-39.

35. Patti AM, Toth PP, Giglio RV, Banach M, Noto M, Nikolic D, Montalto G, Rizzo M. Nutraceuticals as an important part of combination therapy in Dyslipidaemia. Curr Pharm Des. 2017;23:2496-503.

36. Santana-Galvez J, Cisneros-Zevallos L, Jacobo-Velazquez DA. Chlorogenic acid: recent advances on its dual role as a food additive and a nutraceutical against metabolic syndrome. Molecules. 2017;22(3). https://doi.org/10.3390/ molecules22030358.

\section{Ready to submit your research? Choose BMC and benefit from:}

- fast, convenient online submission

- thorough peer review by experienced researchers in your field

- rapid publication on acceptance

- support for research data, including large and complex data types

- gold Open Access which fosters wider collaboration and increased citations

- maximum visibility for your research: over $100 \mathrm{M}$ website views per year

At BMC, research is always in progress.

Learn more biomedcentral.com/submissions 